\title{
Stimulation with a Monoclonal Antibody (mAb4E4) of Scavenger Receptor-mediated Uptake of Chemically Modified Low Density Lipoproteins by THP-1-derived Macrophages Enhances Foam Cell Generation
}

\author{
Paul Holvoet, ${ }^{\star}$ Graciela Perez, ${ }^{\star}$ Hilde Bernar, ${ }^{*}$ Els Brouwers, ${ }^{\star}$ Berlinda Vanloo, ${ }^{\star}$ Maryvonne Rosseneu, ${ }^{\star}$ and Désiré Collen ${ }^{\star}$ \\ ${ }^{*}$ Center for Molecular and Vascular Biology, University of Leuven, B-3000 Leuven, Belgium; and ${ }^{\ddagger}$ Department of Clinical Chemistry, \\ A.Z. St.-Jan, B-8000 Brugge, Belgium
}

\begin{abstract}
mAb4E4, a murine monoclonal antibody that is specific for acetylated LDL and malondialdehyde-treated LDL, binds specifically to modified LDL present in human atherosclerotic lesions. It is directed against an epitope that is poorly exposed in delipidated and solubilized apolipoprotein B-100 from modified LDL.

mAb4E4, as well as its $F\left(a^{\prime}\right)_{2}$ and Fab fragments, enhanced the uptake of both acetylated LDL and malondialdehyde-treated LDL by THP-1-derived macrophages resulting in a sixfold increase of cytoplasmic cholesteryl ester levels. The increased uptake of modified LDL/mAb4E4 complexes did not occur via the $\mathrm{Fc}$ receptor and did not depend on aggregation of modified LDL particles. However, their uptake was inhibited by blocking the scavenger receptors with fucoidin or by downregulation of receptor expression with endotoxins or interferon- $\gamma$, indicating that their uptake is mediated via these receptors. Thus, generation of autoimmune antibodies against modified LDL and subsequent endocytosis of soluble modified LDL/antibody complexes via scavenger receptors may enhance foam cell generation. This mechanism may contribute to the progression of atherosclerotic lesions. (J. Clin. Invest. 1994. 93:89-98.) Key words: atherosclerosis • low density lipoprotein $\bullet$ monoclonal antibodies $\bullet$ immune complexes
\end{abstract}

\section{Introduction}

Subendothelial accumulation of foam cells, primarily derived from monocytes/macrophages by uptake of LDL plays a key role in the initiation of atherosclerosis (1-7). However, incubation of macrophages with LDL in vitro does not produce foam cells because increased intracellular cholesterol levels downregulate the LDL receptor $(2,6)$. In contrast, macrophages avidly accumulate LDL that are chemically modified by acetylation $(A c L D L)^{1}(3)$, malondialdehyde treatment

Address correspondence and reprint requests to Paul Holvoet. Center for Molecular and Vascular Biology, University of Leuven. Campus Gathuisberg. O \& N, Herestraat 49, B-3000 Leuven. Belgium.

Received for publication 31 December 1992 and in revised form 20 Jully 1993

1. Abbreviations used in this paper: AcLDL, acetylated LDL: CE. cholesteryl esters: $\mathrm{CO}$, cholesteryl oleate: $\mathrm{CP}$, cholesteryl palmitate: DPPC. dipalmitoylphosphatidylcholine; $K_{\mathrm{a}}$, equilibrium association constant; $K_{\text {as }}$, binding constant of the antibody for soluble antigen; LPDS, lipoprotein-deficient serum: MDA-LDL, malondialdehyde-treated LDL. Ox-LDL. oxidized LDL: UC. unesterified cholesterol.

J. Clin. Invest.

(C) The American Society for Clinical Investigation, Inc.

$0021-9738 / 94 / 01 / 089 / 10 \$ 2.00$

Volume 93. January 1994. 89-98
(MDA-LDL) (8), or oxidation (Ox-LDL) $(9,10)$ by uptake via scavenger receptors that are unresponsive to intracellular cholesterol levels (6). Furthermore, in murine peritoneal macrophages, modified LDL from human atherosclerotic lesions are accumulated more avidly than native LDL and induce foam cell generation (11-13).

Modified LDL have been demonstrated in atherosclerotic lesions in Watanabe heritable hyperlipidemic rabbits with the use of monoclonal antibodies specific for oxidized LDL, MDA-lysine, and 4-hydroxynonenal-lysine (14-16). In addition, oxidized LDL is immunogenic and specific autoantibodies have been found both in serum and in atherosclerotic lesions in man $(13,17)$. The titer of autoantibodies to MDALDL appears to correlate with progression of carotid atherosclerosis (18).

In the present study, we produced and characterized a murine $\mathrm{IgG}_{1}$ monoclonal antibody, $\mathrm{mAb} 4 \mathrm{E} 4$, cross-reacting with AcLDL and MDA-LDL, but not with native LDL. Purified mAb4E4 and its $F\left(a b^{\prime}\right)_{2}$-fragment were found to enhance the uptake of AcLDL and the accumulation of cholesteryl esters in human macrophages derived from THP-1 monocytic leukemia cells by induction with phorbolesters (19). The time course of the uptake of AcLDL and of AcLDL/antibody complexes, the nature of the receptors responsible for uptake, the hydrolysis of the accumulated cholesteryl esters in the lysosomes, the reesterification of generated cytoplasmatic cholesterol, and the efflux of accumulated cholesterol were characterized.

\section{Methods}

Loil-density lipoprotein preparation and modification. LDL were isolated from pooled sera of fasting normolipidemic donors by sequential ultracentrifugation at densities between 1.03 and $1.05 \mathrm{~g} / \mathrm{ml}$, in an ultracentrifuge (model L7-65; Beckman Instruments. Inc.. Fullerton, CA) for $16 \mathrm{~h} \mathrm{(20)}$ and were dialyzed at $4^{\circ} \mathrm{C}$ against $0.15 \mathrm{M} \mathrm{NaCl}$ containing $0.1 \mathrm{~g} / 1$ EDTA $(\mathrm{pH} \mathrm{7.5)}$ ). Lipoprotein-deficient fetal calf serum (LPDS) $(\mathrm{d}>1.215 \mathrm{~g} / \mathrm{ml})$ was prepared by differential ultracentrifugation as previously described (21). AcLDL, MDA-LDL, and OxLDL were prepared and characterized as described $(10,22,23)$. Reactive free amino groups were measured with 2.4,6-trinitrobenzene sulfonic acid (TNBS reactivity) as described by Habeeb (24). All lipoprotein preparations were sterilized by filtration, using a $0.45 \mu \mathrm{m}$ low protein binding filter (Millex: Millipore Corp., Brussels, Belgium), stored at $4^{\circ} \mathrm{C}$ and used within $2 \mathrm{wk}$. Sodium oleate/ BSA (oleate/BSA) complexes were prepared as previously described (25). Delipidation of LDL was performed as previously described (26).

Isolation of apolipoprotein A-I and preparation of apolipoprotein A-I/phospholipid complexes. Apo A-I was purified from high density lipoproteins that were isolated from plasma and delipidated as previously described (27). Discoidal complexes of apo A-I with dipalmitoylphosphatidylcholine (Sigma Immunochemicals, St. Louis, MO) were prepared at a phospholipid/apolipoprotein weight ratio of 3:1 by the 
cholate dialysis method (28). The complexes were isolated by gelfiltration on a Superose 6PG column as described earlier (27).

Production of monoclonal antibodies. BALB/c mice were immunized with AcLDL using a previously described immunization protocol (29). P3X63-Ag 8-6.5.3 myeloma cells were fused with spleen cells from immunized BALB/c mice according to established procedures (30). After selection of hybridoma cells in the presence of aminopterin, the supernatants were screened for specific antibody production in $\mathrm{mi}-$ cro-ELISA ( 31 ). Positive clones were subcloned by limiting dilution.

- IgGs were purified from ascites fluid on protein A-Sepharose (32). The subclass of the monoclonal antibodies was identified using rabbit antisera against murine $\operatorname{IgM}, \operatorname{IgG}, \operatorname{IgG}_{1}, \operatorname{IgG}_{2 b}, \operatorname{IgG}_{3}, \kappa$ chain, $\lambda$ chain, and goat antisera against mouse $\operatorname{IgG}_{2 \mathrm{a}}$ (Nordic, Tilburg, The Netherlands). The binding constants of ${ }^{125}$ I-labeled antibodies for immobilized native LDL, AcLDL, MDA-LDL and Ox-LDL was assessed in a solid phase assay as previously described (33). The different antigens were dissolved to a concentration of $2 \mu \mathrm{g} / \mathrm{ml}$ in PBS, $\mathrm{pH} 7.4$, containing $20 \mu \mathrm{M}$ of vitamin $\mathrm{E}$, to avoid oxidation of LDL during coating on the plates. After incubation for $16 \mathrm{~h}$ at $4^{\circ} \mathrm{C}$, the wells were emptied and washed several times with a $0.1 \%$ BSA solution in PBS, pH 7.4. Saturation of the well surface was accomplished by incubation of $200 \mu \mathrm{l}$ of a $1 \%$ BSA solution in the same buffer for $1 \mathrm{~h}$ at room temperature. Varying concentrations of the ${ }^{125} \mathrm{I}$-labeled antibody (between 0.8 and $80 \mathrm{nM}$ ), dissolved in $200 \mu \mathrm{l}$ PBS, were added to the coated wells and incubated for $2 \mathrm{~h}$ at room temperature. Three replicate experiments were performed for each antibody concentration. The solution was removed and the wells were washed three times with a $1 \%$ BSA solution. After the final wash, the solution was removed, the bound radioactivity in the individual wells was measured in a gamma counter, and the amount of bound antibody was calculated from the level of bound radioactivity, after correction for nonspecific binding on BSA coated wells. The inverse of the concentration of bound antibodies was plotted versus the inverse of the concentration of free antibodies. The value for $K_{\mathrm{a}}$ was derived from the intercept on the $\mathrm{x}$ axis, whereas the maximal number of binding-sites per ligand molecule was derived from the intercept on the y axis.

To determine the number of ligand molecules that were immobilized in the wells, radiolabeled ligand $(2 \mu \mathrm{g} / \mathrm{ml})$ was added to the wells and the amount of immobilized ligand was derived from the amount of bound radioactivity.

Alternatively, the binding constants of unlabeled antibodies for both immobilized and soluble native LDL, AcLDL, MDA-LDL, and Ox-LDL were assessed in ELISA according to Hogg et al. (34). Immobilization of antigen and incubation of the antibodies occurred as in the solid phase radioimmunoassay. The absorbance, measured at $405 \mathrm{~nm}$ $\left(A^{405}\right)$ is a measure of the amount of bound antibodies. The ratio of $A^{405}$ versus the molar antibody concentration $\left(m_{A}\right)$ was plotted versus $\mathrm{A}^{405}$. The value for $K_{\mathrm{ax}}$, the binding constant of the antibody for immobilized antigen, was derived from the slope of the line. Consequently, the different antibodies were incubated in the presence of increasing amounts of unlabeled antigen, resulting in a dose-dependent inhibition of the binding of the antibodies to immobilized antigen. The ratio of the absorbance measured in the absence $\left(\mathrm{A}_{\mathrm{o}}{ }^{405}\right)$ versus the absorbance measured in the presence of competing soluble antigen $\left(\mathrm{A}_{\mathrm{s}}^{405}\right)$ was plotted versus the molar concentration of competing soluble antigen $\left(\mathrm{m}_{\mathrm{s}}\right)$. The value for $K_{\text {as }}$, the binding constant of the antibody for soluble antigen, was derived from the slope of the line.

$\mathrm{F}\left(\mathrm{ab}^{\prime}\right)_{2}$ fragments were prepared by pepsin digestion as described earlier ( 35 ). Fab fragments were prepared by papain digestion in the presence of $0.01 \mathrm{M}$ cysteine as described (36). The Fc fragments were removed by chromatography on protein A-Sepharose. $F(a b)_{2}^{\prime}$ and Fab preparations were free of intact IgG, as was shown on SDS-PAGE.

Cells. Human THP-1 monocytic leukemia cells (19) were obtained from the American Type Culture Collection (Rockville, MD) and maintained in suspension in T-75 culture flasks at a cell density of 2 $\times 10^{5}-1 \times 10^{6}$ cells $/ \mathrm{ml}$ in RPMI 1640 medium containing $10 \%$ fetal calf serum and $25 \mu \mathrm{g} / \mathrm{ml}$ Gentamycin at $37^{\circ} \mathrm{C}$ in a $10 \% \mathrm{CO}_{2}$ atmosphere. Cells cultured in the presence of PMA (at a final concentration of $10^{-7} \mathrm{M}$ ) were seeded in 35-mm culture dishes (Costar Corp., Cambridge, MA) at a density of $2 \times 10^{6}$ cells $/ \mathrm{ml}$ and incubated for $24 \mathrm{~h}$ (37). Induction of macrophage differentiation in THP-1 cells was characterized by increased adherence of cells to culture dishes and typical changes in cell morphology. Thereafter, the cells were incubated for 24 $\mathrm{h}$ in medium containing 10\% of LPDS.

Uptake of AcLDL and accumulation of cholesteryl esters in THP-1-derived macrophages. Cellular uptake and metabolism of unesterified cholesterol (UC) and cholesteryl esters (CE) was evaluated in THP-1-derived macrophages during incubation with AcLDL or AcLDL/antibody complexes for $24 \mathrm{~h}$. Cells were washed with serumfree medium, and RPMI 1640 medium containing 10\% LPDS and AcLDL (at final concentrations between 10 and $400 \mu \mathrm{g} / \mathrm{ml} ; 1 \mathrm{ml}$ per culture dish) or AcLDL/antibody complexes (antibody concentrations ranging between 0.062 and $2 \mathrm{mg} / \mathrm{ml}$ ) were added to the cells. When indicated, oleate/BSA complexes (25) were added at a final concentration of $100 \mu \mathrm{g}$ oleate $/ \mathrm{ml}$ culture medium. After incubation for $24 \mathrm{~h}$, the cells were washed twice with physiological saline, removed from the dishes using a cell scraper (Becton Dickinson Labware, Lincoln Park, NJ), and centrifuged at $1,000 \mathrm{~g}$ for $10 \mathrm{~min}$ at room temperature. The lipids were extracted from the cell pellet by addition of $5 \mathrm{ml}$ hexane/isopropanol $(3: 2, \mathrm{vol} / \mathrm{vol})$ containing $10 \mu \mathrm{g} / \mathrm{ml}$ cholesteryl heptadecanoate as an internal CE standard and $10 \mu \mathrm{g} / \mathrm{ml}$ beta-sitosterol as a UC standard. The concentrations of UC, total CE, cholesteryl arachidonate, cholesteryl linoleate, cholesteryl oleate (CO), and cholesteryl palmitate $(\mathrm{CP})$ in the cell extracts were measured as described below. In parallel experiments, cells were resuspended in water and sonicated, and lysed cells were centrifuged. The intracellular concentrations of mAb4E4 were determined in ELISA using AcLDL-coated plates and peroxidase-labeled rabbit anti-mouse IgG. The intracellular apo B-100 were measured in ELISA as described previously (38).

Analytical techniques. The levels of UC and of CE in the cell extracts were quantified by HPLC on a reversed phase column (Zorbax ODS; Du Pont de Nemours, Wilmington, DE) (39). UC and CE were eluted isocratically at $45^{\circ} \mathrm{C}$ with a mixture of acetonitrile/isopropanol at ratios of 50:50 and 90:10 ( vol/ $\mathrm{vol})$, respectively. Cellular proteins were dissolved in $0.1 \mathrm{M} \mathrm{NaOH}$ and were quantified by the method of Lowry et al. (40), using bovine serum albumin as a standard.

For microscopical evaluation of lipid accumulation in the cells, the cultures were washed with PBS, fixed for $1 \mathrm{~h}$ with $4 \%$ formaldehyde in PBS, and then briefly immersed in $60 \%$ isopropanol. Cells were stained with $1 \%$ oil red 0 in $60 \%$ isopropanol for $1 \mathrm{~h}$ at $4{ }^{\circ} \mathrm{C}$, rinsed in PBS, and mounted for light microscopic evaluation. Previously established criteria were used for identifying foam cells (4).

Eflux of cholesterol from cells enriched in $C E$. To determine the spontaneous efflux of cholesterol from cells enriched in CE by incubation with AcLDL or AcLDL/antibody complexes, they were washed twice with serum-free RPMI 1640 and incubated for $24 \mathrm{~h}$ in serum-free RPMI medium, containing $1 \mathrm{mg} \mathrm{HSA} / \mathrm{ml}$. To determine acceptor-facilitated efflux of cellular cholesterol, apo A-I/dipalmitoylphosphatidylcholine (apo A-I / DPPC) complexes ( final concentration $=200$ and $400 \mu \mathrm{g}$ apo A-I $/ \mathrm{ml}$ ) were added. At the end of the 24-h incubation period, the cells were collected and the cellular lipids and cellular proteins were extracted as described above. In control experiments, equivalent amounts of DPPC not complexed with apo A-I were added.

Immunocytochemistry. Endarterectomy specimens obtained from patients with confirmed carotid atherosclerosis were treated essentially as described by Rosenfeld et al. (41). The specimens were collected in $0.1 \mathrm{M}$ sodium phosphate buffered saline ( $\mathrm{pH} \mathrm{7.4)}$ ) containing $4 \%$ sucrose, $20 \mu \mathrm{M}$ vitamin $\mathrm{E}$ as an antioxidant, and $1 \mathrm{mM}$ EDTA, snapfrozen with isopentane, cooled in liquid nitrogen, and stored at $-70^{\circ} \mathrm{C}$. Serial 8- $\mu \mathrm{m}$ thick sections were cut and stained with hematoxylin and eosin. Duplicate slides, containing each four to six sections, were developed with mAb4E4, mAb34D8, mAb14F8, and mAb17C8 (final concentration $=10 \mu \mathrm{g} / \mathrm{ml}$ ), with PG-M1, a murine monoclonal antibody specific for human macrophages, or with $1 \mathrm{~A} 4$, a murine monoclonal antibody specific for human $\alpha$-smooth muscle actin, both from Dako (Glostrup, Denmark). Bound antibodies were detected with peroxi- 
dase-labeled rabbit anti-mouse Ig antibodies and diaminobenzidine Specificity of binding of monoclonal antibodies to the tissue sections was evaluated by adding MDA-LDL or native LDL (final concentrations $=100 \mu \mathrm{g} / \mathrm{ml}$ ) to the incubation mixtures.

Chemicals. All cell culture media and solutions were obtained from Gibco-BRL (Ghent, Belgium). Cytochalasin D, dipalmitoylphosphatidylcholine, fucoidin, papain, pepsin, phorbol myristate acetate, and oleate were obtained from Sigma Immunochemicals. Lipopolysaccharide was from Difco Laboratories (Detroit, MI) and interferon- $\gamma$ (specific activity of $25.10^{6} \mathrm{U} / \mathrm{mg}$ ) was from Janssen Biochimica (Geel, Belgium).

\section{Results}

Modification of amino acids in apo B-100. The number of reactive lysine residues in apo B-100, as detected with 2,4,6trinitrobenzene, was 324 as compared to the total number of 356 lysine residues in apo B-100. In the AcLDL and MDALDL, only 121 and 49 lysine residues were accessible. The number of reactive amino groups in MDA-LDL decreased with increasing amounts of MDA in the incubation mixture. When 168 moles MDA was bound per mole LDL (standard preparations), only 80 free lysines could be titrated (42).

Identification and characterization of the monoclonal antibodies. Supernatants of hybridomas resulting from fusions of P3X63-Ag8-6.5.3 myeloma cells with spleen cells of mice immunized with AcLDL or MDA-LDL were screened for specific antibody production in micro-ELISA. The wells were coated with $4 \mu \mathrm{g} / \mathrm{ml}$ solutions of AcLDL, MDA-LDL, Ox-LDL, and native LDL, respectively. Alternatively, wells were coated with acetylated albumin, maleylated albumin, MDA-albumin, and maleylated LDL $(25,42)$. Only hybridomas that produced antibodies that were specific for AcLDL and/or MDA-LDL and/ or Ox-LDL were selected. Out of four fusions, $\sim 400$ hybridomas were obtained, which produced monoclonal antibodies directed against epitopes in AcLDL, 37 of which did not crossreact with native LDL. Four of these hybridomas are further described in the present study. The IgG fraction of these antibodies was purified by affinity chromatography on protein ASepharose. These antibodies only reacted with antibodies against murine $\operatorname{IgG}$ and $\operatorname{IgG}_{1}$, but not with antibodies against murine $\mathrm{IgM}, \mathrm{IgG}_{2}$, and $\mathrm{IgG}_{3}$. The light chains of all antibodies were of the $\kappa$ type.

Binding constants for the interaction of ${ }^{125} \mathrm{I}$-labeled IgG with native LDL, AcLDL, and MDA-LDL were determined in a solid-phase assay as described in methods. Less than $1 \%$ of the added ${ }^{125}$ I-labeled IgG bound aspecifically to wells coated with BSA. The binding data were analyzed by a modified Scatchard plot (33). The equilibrium association constants, $K_{\mathrm{a}}$, of $\mathrm{mAb4E4}, \mathrm{mAb34D8}, \mathrm{mAb} 14 \mathrm{~F} 8$, and mAb17C8 for AcLDL are $7 \pm 1 \times 10^{9} \mathrm{M}^{-1}, 14 \pm 3 \times 10^{9} \mathrm{M}^{-1}, 8 \pm 2 \times 10^{9} \mathrm{M}^{-1}$, and $2 \pm 0.4 \times 10^{9} \mathrm{M}^{-1}$, respectively. The number of apo B-100 molecules that bound per well after incubation of radiolabeled ligand was $1.5 \pm 0.2 \times 10^{11}($ mean $\pm \mathrm{SD} ; n=12)$. The number of binding sites per well was $2.6 \pm 0.4 \times 10^{11}$ for mAb4E4, 1.2 \pm 0.1 $\times 10^{11}$ for mAb34D8, $3.2 \pm 0.4 \times 10^{11}$ for mAb14F8, and $12 \pm 3$ $\times 10^{11}$ for mAb17C8. Thus, the calculated maximal number of binding sites per apo B-100 molecule in AcLDL were approximately one for mAb34D8, two for mAb4E4 and mAb14F8, and eight for $\mathrm{mAb} 17 \mathrm{C8}$. Delipidation of $\mathrm{AcLDL}$ and resolubilisation of its apo B-100 moiety (26) did not alter the affinity of
mAb17C8. In contrast, the $K_{\mathrm{a}}$ values of mAb4E4, mAb34D8, and mAbl4F8 decreased 20-, 100-, and 30-fold, respectively, suggesting that the epitopes for the latter antibodies were not efficiently reconstituted in resolubilized apo B-100 of AcLDL. The $K_{\mathrm{a}}$ and the number of binding sites per apo B-100 molecule in MDA-LDL of mAb4E4 were identical to the values obtained for AcLDL. In contrast, the $K_{\mathrm{a}}$ values of the other antibodies for MDA-LDL were at least 100 -fold lower than those for AcLDL. The affinity constants of all antibodies for native $\mathrm{LDL}$ were at least 1,000 -fold lower than for AcLDL (Table I). Furthermore, mAb4E4 did not crossreact with acetylated, maleylated, and malondialdehyde-treated albumin, nor with maleylated $\operatorname{LDL}(25,42)$ (data not shown).

Because the data indicated that mAb4E4, mAb34D8, and mAb14F8 are most probably directed against conformational epitopes that are only efficiently exposed in apo B-100 that is associated with phospholipids, their affinity constants for soluble antigens were determined in ELISA, by measuring the residual binding of antibodies to immobilized antigen in the presence of increasing amounts of soluble antigen (34). The $K_{\mathrm{ax}}$ values of the different antibodies for immobilized Ac-LDL and MDA-LDL measured in ELISA, were not statistically different from those measured in the solid phase radioimmunoassay. The $K_{\text {as }}$ values of the monoclonal antibodies mAbAE4, $\mathrm{mAb} 34 \mathrm{D} 8$, and $\mathrm{mAb} 14 \mathrm{~F} 8$ for AcLDL were $11 \pm 2 \times 10^{9} \mathrm{M}^{-1}$, $8 \pm 2 \times 10^{9} \mathrm{M}^{-1}$, and $3 \pm 1 \times 10^{9} \mathrm{M}^{-1}$. The $K_{\text {as }}$ value for MDALDL of mAb4E4 was $8 \pm 2 \times 10^{9} \mathrm{M}^{-1}$, whereas the values of all other antibodies were $\leq 10^{6} \mathrm{M}^{-1}$. Furthermore, the $K_{\text {as }}$ values of all antibodies for native $\mathrm{LDL}$ were $\leq 10^{6} \mathrm{M}^{-1}$.

The $K_{\mathrm{a}}$ value of the $\mathrm{F}\left(\mathrm{ab}^{\prime}\right)_{2}$ fragments of mAb4E4 for AcLDL was identical to that of intact IgG, whereas the $K_{\mathrm{a}}$ value of its Fab fragments was threefold lower.

Lipid composition of AcLDL. AcLDL, prepared as described in Methods, contained 35 $\pm 3 \%$ (mean \pm SEM, $n=4$ ) phospholipids, $10 \pm 2 \%$ triglycerides, $15 \pm 1 \%$ UC, and $40 \pm 3 \%$ $\mathrm{CE}$. Thus, the CE/UC ratios in the AcLDL preparations were $2.7 \pm 0.2$. The $C E$ fraction contained $8 \pm 1 \%$ cholesteryl arachidonate, $57 \pm 3 \%$ cholesteryl linoleate, $20 \pm 2 \% \mathrm{CO}$, and $15 \pm 2 \%$ CP.

Accumulation of cholesterol in THP-1-derived macrophages incubated with ACLDL or MDA-LDL. When $2 \times 10^{6}$ THP-1-derived macrophages were incubated in RPMI medium containing 10\% LPDS for $24 \mathrm{~h}$ (blank cells), they were found to contain $29 \pm 2 \mu \mathrm{g}$ UC and $<2 \mu \mathrm{g}$ CE per mg cell protein (mean \pm SEM, $n=6$ ) (Table II). Addition of native LDL ( final concentrations $\leq 400 \mu \mathrm{g} / \mathrm{ml}$ ) did not produce a significant increase of the $\mathrm{CE}$ levels, in agreement with the earlier

Table I. Equilibrium Association Constants, $K_{a}$, of Monoclonal Antibodies $m A b 4 E 4, m A b 34 D 8$, and $m A b 14 F 8$ for Soluble AcLDL, MDA-LDL, and Native $L D L$

\begin{tabular}{lccc}
\hline & \multicolumn{3}{c}{$\mathrm{K}_{\mathbf{a}}\left(\mathrm{M}^{-1}\right)$} \\
\cline { 2 - 4 } Identification & AcLDL & MDA-LDL & LDL \\
\hline mAb4E4 & $11 \pm 2 \times 10^{9}$ & $8 \pm 2 \times 10^{9}$ & $\leq 10^{6}$ \\
mAb34D8 & $8 \pm 2 \times 10^{9}$ & $\leq 10^{6}$ & $\leq 10^{6}$ \\
mAb14F8 & $3 \pm 1 \times 10^{9}$ & $\leq 10^{6}$ & $\leq 10^{6}$ \\
& & & \\
\hline
\end{tabular}

The results represent means \pm SD for four independent determinations. 
Table II. Effect of MAb4E4 on the Uptake of AcLDL and Accumulation of CE in THP-1-derived Macrophages

\begin{tabular}{|c|c|c|c|c|c|c|}
\hline AcLDL & mAb4E4 & $n$ & UC & $\mathrm{CE}$ & $\mathrm{CO}$ & $\mathrm{CP}$ \\
\hline$\mu g / m l$ & $\mathrm{mg} / \mathrm{ml}$ & & $\mu \mathrm{g} / \mathrm{mg}$ protein & $\mu \mathrm{g} / \mathrm{mg}$ protein & $\mu g / m g$ protcin & $\mu g / m g$ protein \\
\hline 0 & 0 & 6 & $29 \pm 2$ & $<2.0$ & $<2.0$ & $<2.0$ \\
\hline 10 & 0 & 3 & $25 \pm 1$ & $6.0 \pm 0.3$ & $2.7 \pm 0.3$ & $3.6 \pm 0.5$ \\
\hline 10 & 0.025 & 3 & $38 \pm 0.4^{*}$ & $15 \pm 0.3^{*}$ & $4.8 \pm 0.1$ & $7.2 \pm 0.1$ \\
\hline 25 & 0 & 6 & $44 \pm 2 *$ & $9.0 \pm 1$ & $4.0 \pm 0.4$ & $3.6 \pm 0.3$ \\
\hline 100 & 0 & 8 & $62 \pm 4$ & $15 \pm 1$ & $5.4 \pm 0.3$ & $7.1 \pm 0.4$ \\
\hline 100 & 0.062 & 5 & $53 \pm 6$ & $22 \pm 2^{\ddagger}$ & $6.8 \pm 0.6$ & $9.5 \pm 0.8^{\ddagger}$ \\
\hline 100 & 0.25 & 5 & $90 \pm 8^{\ddagger}$ & $70 \pm 6^{8}$ & $17 \pm 2^{\S}$ & $16 \pm 0.7^{\S}$ \\
\hline 100 & 1.0 & 4 & $110 \pm 7^{\S}$ & $98 \pm 13^{\S}$ & $22 \pm 3^{\S}$ & $20 \pm 2^{\S}$ \\
\hline
\end{tabular}

The data represent means $\pm \mathrm{SE}$ of the means. Comparison of the different parameters was performed using Student's $t$ test with levels of significance of ${ }^{*} P<0.001$ vs $10 \mu \mathrm{g}$ AcLDL per ml, ${ }^{\ddagger} P<0.01$ vs $100 \mu \mathrm{g} \mathrm{AcLDL} / \mathrm{ml}$ and ${ }^{\S} P<0.001$ vs $100 \mu \mathrm{g} \mathrm{AcLDL} / \mathrm{ml}$.

observation that phorbol ester-stimulated THP-1 cells lose their ability to degrade native LDL because of rapid degradation of the LDL receptors (43).

Incubation of $2 \times 10^{6}$ THP-1-derived macrophages with AcLDL at final concentrations between 10 and $100 \mu \mathrm{g} / \mathrm{ml}$ resulted in a dose-dependent increase of the cellular cholesterol levels. The UC levels increased from $25 \pm 1(n=3, P=\mathrm{NS}$ versus blank cells) to $62 \pm 4 \mu \mathrm{g}(n=8, P<0.001) / \mathrm{mg}$ cell protein (Table II). The CE increased from $6.0 \pm 0.3$ to $15 \pm 1 \mu \mathrm{g}$ $(P=0.001$ versus $10 \mu \mathrm{g} / \mathrm{ml}$ AcLDL) $/ \mathrm{mg}$ cell protein (Table II). The 2.5-fold increase of the $\mathrm{CE}$ levels was associated with a twofold increase of both the $\mathrm{CO}$ and $\mathrm{CP}$ levels (Table II). The data for cells incubated with $100 \mu \mathrm{g}$ AcLDL are summarized in Fig $1 \mathrm{~A}$. Addition of $400 \mu \mathrm{g}$ AcLDL/ml did not produce a significant increase of the CE levels in the THP-1-derived macrophages. Addition of $50 \mu \mathrm{g} \mathrm{MDA}-\mathrm{LDL} / \mathrm{ml}$ resulted in an in-

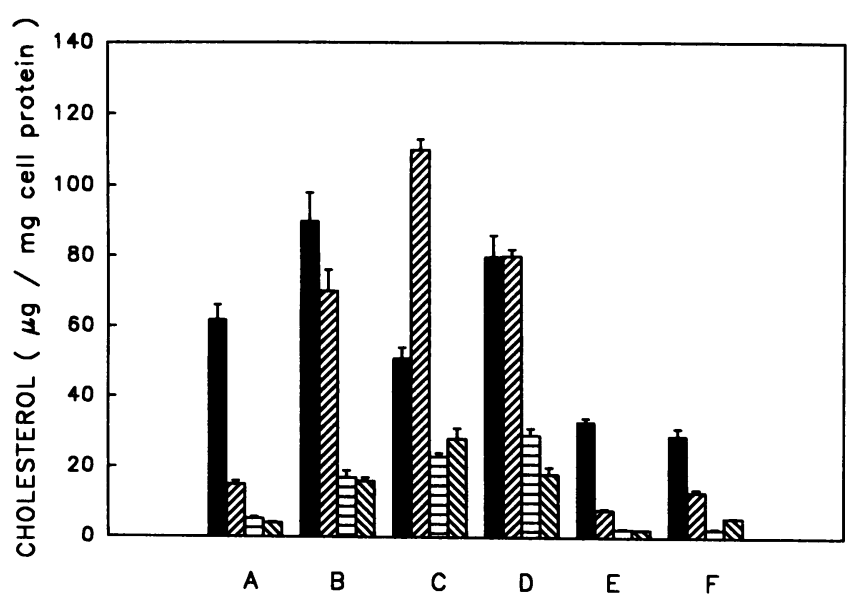

Figure 1. Uptake and degradation of AcLDL and AcLDL/mAb4E4 complexes by THP-1-derived macrophages: $(A)$ cells incubated with $100 \mu \mathrm{g}$ AcLDL, $(B)$ cells incubated with AcLDL/mAb4E4 complexes

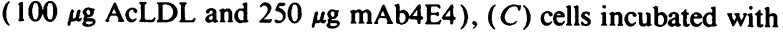
AcLDL/mAb4E4 complexes in the presence of chloroquine, $(D)$ cells incubated with AcLDL/mAb4E4 complexes and supplemented with oleate/BSA complexes, $(E)$ cells incubated with AcLDL/mAb4E4 complexes in the presence of fucoidin, and $(F)$ cells incubated with AcLDL/mAb4E4 complexes after pretreatment with endotoxin. Levels of unesterified cholesterol $(\square)$, total cholesteryl esters ( $(\square)$, cholesteryl oleate (国), and cholesteryl palmitate (四) are represented. crease of the UC and CE levels to $45 \pm 3 \mu \mathrm{g} / \mathrm{mg}(n=4, P$ $<0.001$ versus untreated cells) and $15 \pm 2 \mu \mathrm{g} / \mathrm{mg}(n=4, P$ $<0.001$ ), respectively.

Accumulation of cholesterol in THP-1-derived macrophages incubated with AcLDL/mAb4E4 complexes or MDA$L D L / m A b 4 E 4$ complexes. Addition of mAb4E4 (62, 250, and $1,000 \mu \mathrm{g} / \mathrm{ml}$, respectively) to the incubation mixtures containing $100 \mu \mathrm{g} \mathrm{AcLDL} / \mathrm{ml}$ resulted in a dose-dependent increase of both the UC levels and of the CE levels in the THP-1-derived macrophages ( Table II). The data for cells incubated with 100 $\mu \mathrm{g} \mathrm{AcLDL} / \mathrm{ml}$ in the presence of $250 \mu \mathrm{g} \mathrm{mAb4E4/ml}$, are summarized in Fig. $1 B$. Thus, uptake and degradation of these AcLDL/mAb4E4 complexes resulted in $(a)$ a fourfold increase of the cellular UC levels as compared to those in untreated cells; $(b)$ a more than 35 -fold increase of the cellular CE levels; and (c) a more than eightfold increase of the cellular $\mathrm{CO}$ and CP levels. The intracellular apo B-100 levels, quantified by ELISA, were below $100 \mathrm{ng} / \mathrm{ml}$, indicating that apo B-100 was degraded. The intracellular mAb4E4 levels were $80 \mu \mathrm{g} / \mathrm{ml}$, indicating that the IgG remained intact. In contrast, the UC, CE, and $\mathrm{CO}$ levels in THP-1-derived macrophages incubated with AcLDL $(100 \mu \mathrm{g} / \mathrm{ml})$ in the presence of mAb14F8, mAb17C8, and $\mathrm{mAb} 34 \mathrm{D} 8$ (at final concentration $\leq 250 \mu \mathrm{g} / \mathrm{ml}$ ) were not significantly different from those in cells preincubated with AcLDL in the absence of mAbs (not shown). Addition of mAb4E4 $(25 \mu \mathrm{g} / \mathrm{ml})$ to incubation mixtures containing $10 \mu \mathrm{g}$ AcLDL $/ \mathrm{ml}$, resulted in a 1.5 -fold increase of the UC levels and a 2.5-fold increase of the CE levels $(P<0.001)$ in the THP-1-derived macrophages (Table II). The CE levels in these cells were not different from those in cells incubated with $100 \mu \mathrm{g} \mathrm{AcLDL} / \mathrm{ml}$ in the absence of mAb4E4 (Table II). Addition of mAb4E4 $(250 \mu \mathrm{g} / \mathrm{ml})$ to incubation mixtures containing $50 \mu \mathrm{g} \mathrm{MDA}-\mathrm{LDL} / \mathrm{ml}$, resulted in an increase of the cellular UC and CE levels to $98 \pm 5 \mu \mathrm{g} / \mathrm{mg}(n=4 ; P<0.001$ versus no antibody) and $80 \pm 2 \mu \mathrm{g} / \mathrm{mg}(P<0.001)$, respectively.

Degradation of modified LDL by THP-1-derived macrophages incubated with AcLDL/mAb4E4 complexes. According to the two-compartment model for CE metabolism in macrophages (2), CE that enter the macrophages via receptor-mediated endocytosis are delivered to lysosomes (first cellular compartment), where the $\mathrm{CE}$ are hydrolyzed. The liberated UC leaves the lysosomes and enters the cytoplasm (second cellular compartment). The free cholesterol is then either translo- 
cated to the membranes, resulting in a further increase of the intracellular UC levels, or is reesterified in the cytoplasm.

Addition of chloroquine $(100 \mu \mathrm{g} / \mathrm{ml})$, an inhibitor of lysosomal hydrolysis (44), to THP-1-derived macrophages incubated with AcLDL/mAb4E4 complexes ( $100 \mu \mathrm{g} \mathrm{AcLDL}$ and $250 \mu \mathrm{g} \mathrm{mAb} 4 \mathrm{E} 4)$ caused a decrease of the UC levels to $51 \pm 1 \mu \mathrm{g}$ ( $n=4 ; P=0.003$ versus cells incubated in the absence of chloroquine ) and an increase of the CE levels to $110 \pm 3 \mu \mathrm{g}(P$ $<0.001$ ) $/ \mathrm{mg}$ cell protein (Fig. $1 C$ ). Thus, the $\mathrm{CE} / \mathrm{UC}$ ratios in the cell extracts were $2.2 \pm 0.06$ as compared to $0.78 \pm 0.07$ ( $P$ $<0.001)$ in the extracts from cells incubated in the absence of chloroquine. These CE/UC ratios were not statistically different from those in the AcLDL preparations before incubation with the cells. These data indicate that the increase of CE levels after uptake of AcLDL/mAb4E4 complexes in the presence of chloroquine was caused by accumulation of unhydrolyzed $\mathrm{CE}$ in the lysosomes, whereas the accumulation of $C E$ levels in the absence of chloroquine was most probably the result of esterification of UC in cytoplasm.

Because oleate is the predominant substrate for acyl CoA:cholesterol acyltransferase-mediated CE synthesis (45) in the cytoplasm, the composition of the cholesterol fraction was determined in cells that were supplemented with oleate. Addition of oleate/BSA complexes (25) (at a final concentration of $100 \mu \mathrm{g}$ oleate $/ \mathrm{ml}$ ) to cells incubated with AcLDL/ mAb4E4 complexes, resulted in cellular UC, CE, and CP levels that were not different from levels measured in cells incubated in the absence of oleate/BSA complexes. However, the CO levels increased from $16 \pm 1$ to $29 \pm 2 \mu \mathrm{g}(P=0.008) / \mathrm{mg}$ cell protein (Fig. 1 D).

Identification of the receptors mediating the uptake of AcLDL and $A c L D L / m A b 4 E 4$ complexes. The uptake of LDL aggregates by macrophages is inhibited by cytochalasin, an inhibitor of phagocytosis (46-48). In the present study, AcLDL aggregates ( $100 \mu \mathrm{g} \mathrm{AcLDL} / \mathrm{ml}$ ) were prepared by mechanical disruption of LDL (48), resulting in an increase of the absorbance at $680 \mathrm{~nm}$ from 0.008 to 0.75 . Incubation of THP-1-derived macrophages with these AcLDL aggregates resulted in an increase of the cellular UC and CE levels to $97 \pm 1(n=3)$ and $96 \pm 3 \mu \mathrm{g} / \mathrm{mg}$, respectively. Addition of cytochalasin D (final concentration $40 \mu \mathrm{g} / \mathrm{ml}$ ), resulted in a decrease of the UC and CE levels to $39 \pm 1(n=3, P<0.001)$ and $36 \pm 1(P<0.001)$ $\mu \mathrm{g} / \mathrm{mg}$, respectively. In contrast, the uptake of AcLDL/ mAb4E4 complexes (at an antibody concentration of $\leq 250$ $\mu \mathrm{g} / \mathrm{ml}$ ) by THP-1-derived macrophages was not inhibited by cytochalasin $\mathrm{D}$. These results indicate that the uptake of AcLDL/mAb4E4 complexes most probably did not occur via phagocytosis. Increasing the mAb4E4 concentrations to $2 \mathrm{mg}$ / $\mathrm{ml}$ resulted in a twofold further increase of the cellular CE levels. This additional increase was however reverted by addition of cytochalasin D suggesting that, at high antibody concentrations, LDL aggregates are generated that are taken up via phagocytosis, resulting in an additional increase of the cellular CE levels.

The UC, CE. CO, and CP levels in THP-1-derived macrophages incubated with $100 \mu \mathrm{g}$ AcLDL in the presence of $200 \mu \mathrm{g}$ of the $\mathrm{F}\left(\mathrm{ab}^{\prime}\right)_{2}$ fragments of mAb4E4 were $65 \pm 2 \mu \mathrm{g}(n=5 ; P$ $=$ NS vs cells incubated in the absence of $F\left(a b^{\prime}\right)_{2}$ fragments $)$, $83 \pm 2 \mu \mathrm{g}(P<0.001), 16 \pm 0.5 \mu \mathrm{g}(P<0.001)$, and $15 \pm 0.5 \mu \mathrm{g}$ $(P<0.001) / \mathrm{mg}$ cell protein, respectively, and did not differ significantly from the values obtained with $100 \mu \mathrm{g}$ AcLDL in the presence of $0.25 \mathrm{mg} / \mathrm{ml}$ of the intact antibody. Addition of
Fab fragments $(200 \mu \mathrm{g} / \mathrm{ml})$ to the incubation mixtures containing $100 \mu \mathrm{g} \mathrm{AcLDL} / \mathrm{ml}$ resulted in cellular UC levels of $68 \pm 4 \mu \mathrm{g}(n=4 ; P=\mathrm{NS}$ versus cells incubated in the absence of Fab fragments ) per mg cell protein, and in CE levels of $63 \pm 5 \mu \mathrm{g}$ $(P<0.001) / \mathrm{mg}$ cell protein, respectively. These data indicate that the uptake of the immune complexes was not $F_{c}$ receptor mediated. Furthermore, no direct binding of intact IgGs or fragments of mAb4E4 could be observed when radiolabeled IgGs or fragments were added to the cells (not shown).

The addition of fucoidin $(50 \mu \mathrm{g} / \mathrm{ml})$, an antagonist of the scavenger receptor (2), to THP-1-derived macrophages incubated in the presence of AcLDL $(100 \mu \mathrm{g} / \mathrm{ml})$ resulted in a decrease of the UC and CE levels to $29 \pm 5 \mu \mathrm{g}(n=3 ; P=0.001$ versus control $)$ and $7.8 \pm 2.0 \mu \mathrm{g}(P=0.006) / \mathrm{mg}$ cell protein, respectively. The corresponding $\mathrm{CO}$ and $\mathrm{CP}$ levels were $2.7 \pm 0.8 \mu \mathrm{g}(P=0.003)$ and $3.3 \pm 0.7 \mu \mathrm{g}(P<0.001) / \mathrm{mg}$ cell protein, respectively (not shown).

Addition of fucoidin ( $50 \mu \mathrm{g} / \mathrm{ml}$ ) to THP-1-derived macrophages incubated with AcLDL/mAb4E4 complexes ( $100 \mu \mathrm{g}$ AcLDL and $250 \mu \mathrm{g} \mathrm{mAb4E4)} \mathrm{reduced} \mathrm{the} \mathrm{UC}$ and CE levels to $33 \pm 1 \mu \mathrm{g}(P=0.002$ versus control without fucoidin $)$ and $8.1 \pm 0.4 \mu \mathrm{g}(P<0.001) / \mathrm{mg}$ cell protein, respectively (Fig. $1 E$ ).

Endotoxin decreases the low density lipoprotein receptormediated uptake of LDL by HepG2 cells, but cells pretreated with endotoxin for 1-24 h and then with LDL in the absence of endotoxin accumulate and degrade LDL normally (49). These data suggest that endotoxin does not inhibit LDL receptor expression, but that endotoxin-LDL complexes do not bind to the LDL receptor. In contrast, it has been demonstrated by van Lenten and Fogelman ( 50) that treatment of THP-1 cells with endotoxin inhibits scavenger receptor expression through the action of tumor necrosis factor, resulting in a decreased subsequent uptake of chemically modified LDL (50). In the present study, preincubation of THP-1-derived macrophages with LPS ( $100 \mathrm{ng} / \mathrm{ml}$ ) caused a decreased uptake of AcLDL ( 100 $\mu \mathrm{g} / \mathrm{ml})$, yielding decreased UC and CE levels of $28 \pm 2 \mu \mathrm{g}(n$ $=3 ; P<0.001$ versus cells incubated in the absence of LPS) and $6.6 \pm 0.7 \mu \mathrm{g}(P<0.001) / \mathrm{mg}$ cell protein, respectively (data not shown). Preincubation of THP-1 cells with LPS also resulted in a subsequent decreased uptake of the AcLDL/ $\mathrm{mAb} 4 \mathrm{E} 4$ complexes. The cellular UC and CE levels were threeand fivefold lower than the levels in cells that were not pretreated with LPS (Fig. $1 F$ ).

Interferon- $\gamma$ also inhibits the expression of scavenger receptors at the surface of human monocyte-derived macrophages (51). In the present study, PMA-stimulated THP-1 cells were preincubated with interferon- $\gamma$ (final concentration $=300 \mathrm{U} /$ $\mathrm{ml}$ ), before addition of AcLDL/mAb4E4 complexes. The cellular UC and CE levels were $50 \pm 3 \mu \mathrm{g} / \mathrm{mg}(n=3 ; P=0.01$ versus cells not pretreated with interferon- $\gamma$ ) and $38 \pm 1 \mu \mathrm{g} / \mathrm{mg}$ ( $n=3 ; P<0.001)$, respectively. Pretreatment of THP-1 cells with interferon- $\gamma$ resulted in a twofold reduction of the $C E$ levels in cells incubated with AcLDL. These findings are in agreement with previous findings that pretreatment of human monocyte-derived macrophages with interferon- $\gamma(\leq 1,000$ $\mathrm{U} / \mathrm{ml}$ ) resulted in a twofold reduction of the uptake of AcLDL (51).

Time course of the accumulation of cholesterol and $C E$ in THP-1-derived macrophages incubated with AcLDL. Fig. 2 illustrates the time course of the accumulation of cholesterol and cholesteryl esters in THP-1-derived macrophages incu- 


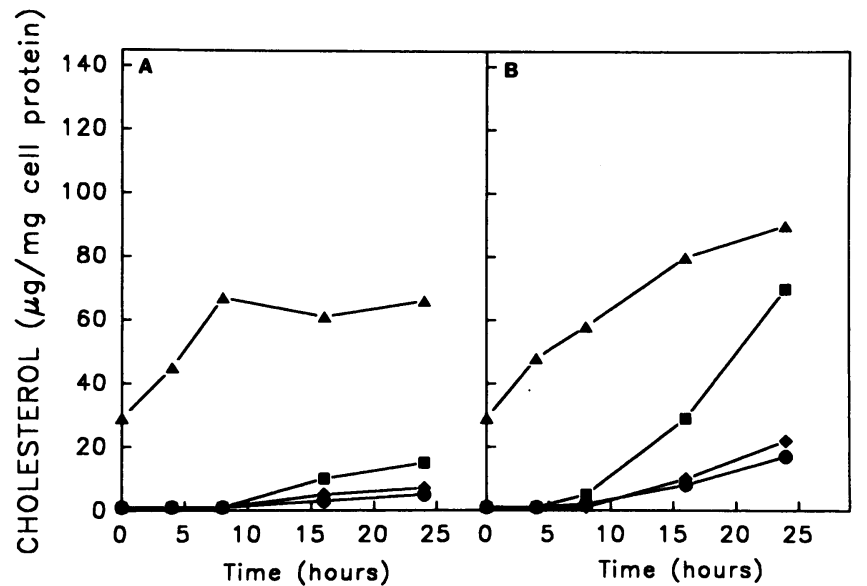

Figure 2. Time course of the accumulation of UC and CE in THP1-derived macrophages incubated for $\leq 24 \mathrm{~h}$ with $\operatorname{AcLDL}(A)$ or with

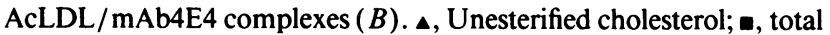
cholesteryl esters; $\bullet$, cholesteryl oleate; $\bullet$, cholesteryl palmitate.

bated with $100 \mu \mathrm{g}$ AcLDL in the absence $(A)$ and in the presence $(B)$ of $250 \mu \mathrm{g}$ of mAb4E4. Both in the absence and in the presence of mAb4E4, the increase of the UC levels preceded that of the $\mathrm{CE}$ levels, suggesting that the increase of $\mathrm{CE}$ was the result of reesterification of $\mathrm{UC}$ transferred to the cytoplasm.

Effect of MAb4E4 on foam cell generation in THP-1-derived macrophages incubated with AcLDL. Fig. 3 represents light micrographs of THP-1 derived macrophages that were incubated with $10 \mu \mathrm{g} \mathrm{AcLDL} / \mathrm{ml}$ in the absence $(A)$ and in the presence of $25 \mu \mathrm{g} \mathrm{Fab}$ fragments of $\mathrm{mAb} 4 \mathrm{E} 4 / \mathrm{ml}(B)$. The lipid droplets in the cytoplasm of the THP-1-derived macrophages were stained with Oil Red 0 . These micrographs illustrate that the number of lipid droplets in the THP-1-derived macro-

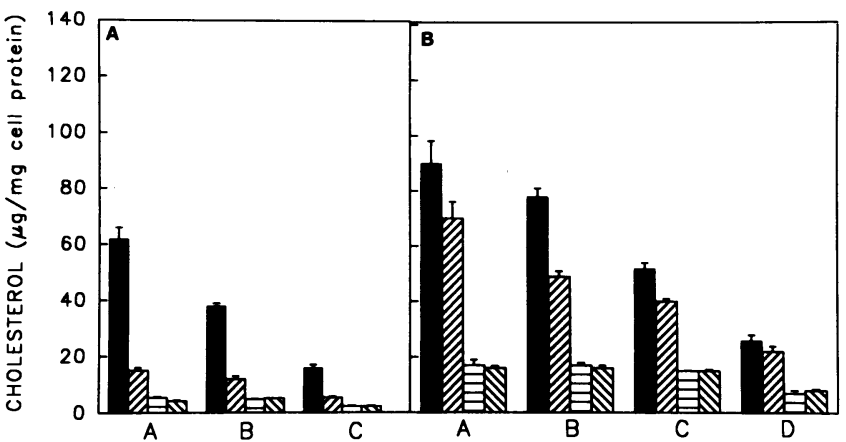

Figure 4. Efflux of cholesterol from lipid-laden THP-1-derived macrophages obtained by incubation with AcLDL $(I)$ or AcLDL/ mAb4E4 complexes $(I I) .(A)$ Cellular cholesterol levels at the end of the loading phase. $(B)$ Spontaneous cholesterol efflux from cholesterol-enriched macrophages after incubation in the presence of $1 \mathrm{mg}$ $\mathrm{HSA} / \mathrm{ml}$ for $24 \mathrm{~h}$. ( $C$ and $D$ ) Acceptor-facilitated cholesterol efflux from cholesterol-enriched macrophages after incubation for $24 \mathrm{~h}$ with apo A-I/DPPC complexes at a final concentration of $200 \mu \mathrm{g} / \mathrm{ml}(C)$ or $400 \mu \mathrm{g} / \mathrm{ml}$ apo A-I $(D)$. Symbols are the same as in Fig. 1 .

phages is indeed augmented when Fab fragments are added to the incubation mixture containing AcLDL. The results indicate that crosslinking of AcLDL particles by the antibody is not required for increased uptake of AcLDL, and enhanced foam cell generation (4).

Efflux of cholesterol from THP-1-derived macrophages enriched in cholesterol by incubation with AcLDL or AcLDL/ mAb4E4 complexes. Incubation for $24 \mathrm{~h}$ of THP-1-derived macrophages, enriched in cholesterol by incubation with AcLDL, in culture medium containing $1 \mathrm{mg} \mathrm{HSA} / \mathrm{ml}$, resulted in a 1.6-fold decrease of the UC levels, whereas the CE did not decrease (Fig. $4 A$ ). Addition of apo A-I/DPPC complexes (at a final concentration of $200 \mu \mathrm{g}$ apo A-I $/ \mathrm{ml}$ ) to the incubation
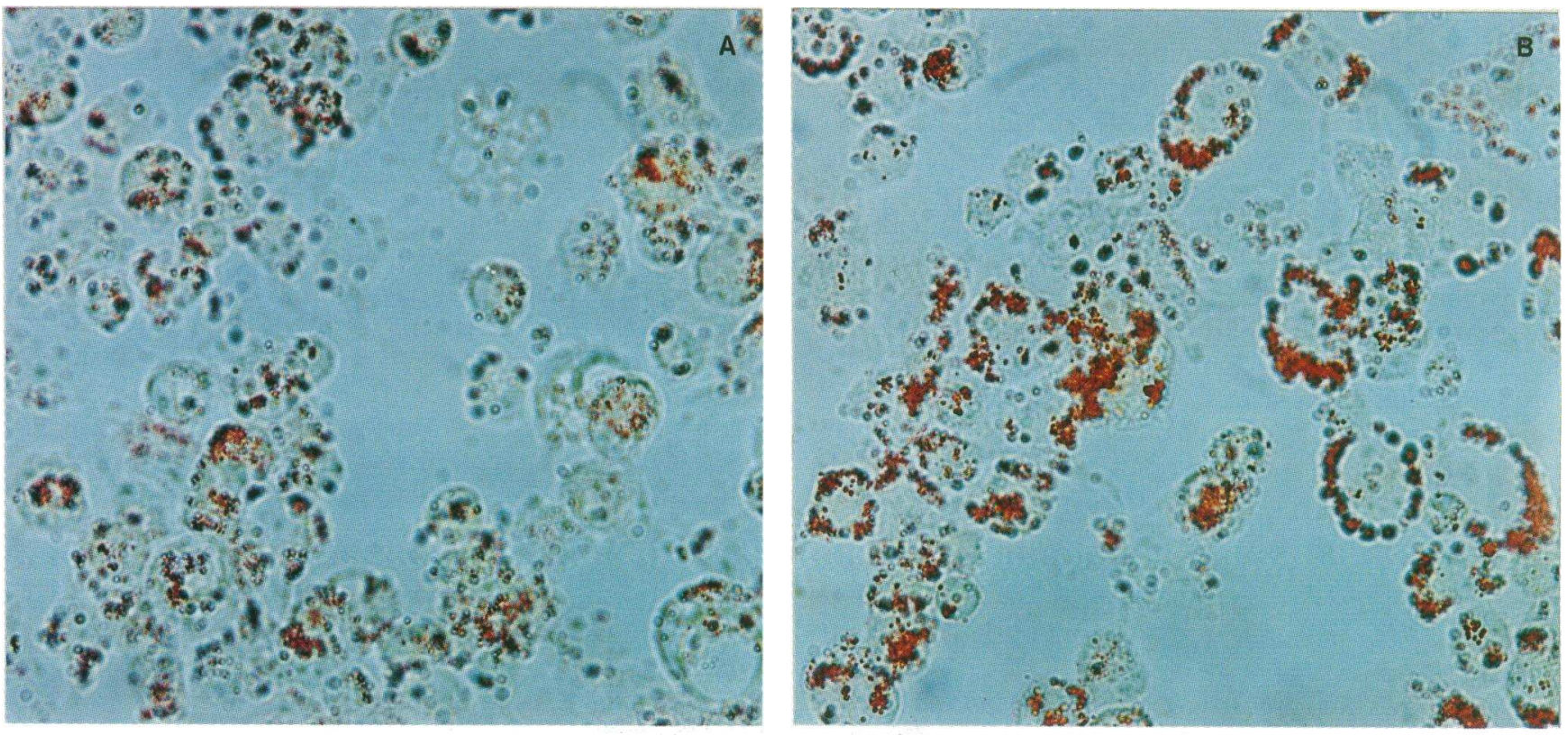

Figure 3. Light micrographs of THP-1-derived macrophages incubated with $10 \mu \mathrm{g} \mathrm{AcLDL}$ in the absence $(A)$ or in the presence of $25 \mu \mathrm{g}$ Fab fragments of mAb4E4 $(B)$. The lipid droplets in the cytoplasm were stained with Oil Red 0 and appear as brown spots $(\times 400)$. 
Table III. Efflux of Cholesterol from THP-1 Cells Preincubated with AcLDL (Final Concentration $=100 \mu \mathrm{g} / \mathrm{ml}$ ) in the Absence or Presence of $\mathrm{mAb4E4}$ (Final Concentration $=0.25 \mathrm{mg} / \mathrm{ml}$ )

\begin{tabular}{|c|c|c|c|c|c|c|c|c|}
\hline \multirow[b]{2}{*}{ Apo A-I/DPPC } & \multicolumn{4}{|c|}{ Absence of mAb4E4 } & \multicolumn{4}{|c|}{ Presence of mAb4E4 } \\
\hline & $n$ & UC & $\mathrm{CE}$ & Cholesteryloleate & $n$ & UC & $\mathrm{CE}$ & Cholesteryloleate \\
\hline$\mu g / m l$ & & $\begin{array}{c}\mu g / m g \text { cell } \\
\text { protein }\end{array}$ & $\begin{array}{c}\mu g / m g \text { cell } \\
\text { protein }\end{array}$ & $\begin{array}{l}\mu g / m g \text { cell } \\
\text { protein }\end{array}$ & & $\begin{array}{l}\mu g / m g \text { cell } \\
\text { protein }\end{array}$ & $\begin{array}{l}\mu \mathrm{g} / \mathrm{mg} \text { cell } \\
\text { protein }\end{array}$ & $\begin{array}{l}\mu \mathrm{g} / \mathrm{mg} \text { cell } \\
\text { protein }\end{array}$ \\
\hline 0 & 3 & $38 \pm 1$ & $12 \pm 0.1$ & $5.0 \pm 0.2$ & 4 & $78 \pm 3$ & $49 \pm 2$ & $17 \pm 1$ \\
\hline 200 & 4 & $16 \pm 1$ & $5.3 \pm 0.4$ & $3.8 \pm 0.2$ & 4 & $52 \pm 2$ & $40 \pm 1$ & $15 \pm 0.2$ \\
\hline 400 & 3 & ND & ND & ND & 3 & $26 \pm 2$ & $22 \pm 2$ & $7 \pm 1$ \\
\hline
\end{tabular}

The results represent means \pm SE of the means. The significance of the differences between the parameters was determined using Student's $t$ test. ( $P=\mathrm{NS},{ }^{\ddagger} P<0.01,{ }^{\S} P<0.001$ ). Efflux of cholesterol was induced by incubating the cells in the presence of apo A-I/DPPC complexes (final concentration $=200 \mu \mathrm{g}$ apo A-I/ml. ND, not determined.

mixture caused a significant decrease of both UC and CE levels (Fig. $4 \mathrm{~B}$ ), corresponding to an efflux of $0.15 \pm 0.01 \mu \mathrm{g}$ cholesterol $/ \mu \mathrm{g}$ apo A-I per $24 \mathrm{~h}$. The residual intracellular CE fraction consisted for $>80 \%$ of $\mathrm{CO}$ and $\mathrm{CP}$, which is indicative of efficient reesterification of cholesterol in the cytoplasm during the efflux phase. Addition of equivalent amounts of DPPC, that were not complexed with apo A-I, resulted in a cholesterol efflux similar to the spontaneous efflux (not shown).

Incubation for $24 \mathrm{~h}$ of THP-1-derived macrophages, enriched in cholesterol by incubation with AcLDL/mAb4E4 complexes ( $100 \mu \mathrm{g}$ AcLDL and $250 \mu \mathrm{g} \mathrm{mAb4E4),} \mathrm{in} \mathrm{culture}$ medium containing $1 \mathrm{mg} \mathrm{HSA} / \mathrm{ml}$, resulted in a 1.2 -fold decrease of the UC levels and in a 1.4-fold decrease of the $\mathrm{CE}$ levels (Fig. 4 C). Addition of apo A-I / DPPC complexes ( 200 $\mu \mathrm{g}$ apo A-I $/ \mathrm{ml}$ ) caused a more pronounced decrease of the UC and CE levels (Fig. $4 \mathrm{D}$ ), corresponding to a total cholesterol efflux of $0.17 \mu \mathrm{g} / \mu \mathrm{g}$ apo A-I per $24 \mathrm{~h}$. Increasing the apo A-I concentration to $400 \mu \mathrm{g} / \mathrm{ml}$ resulted in a larger decrease of the UC and CE levels, corresponding to a total cholesterol efflux of $0.19 \pm 0.02 \mu \mathrm{g} / \mu \mathrm{g}$ apo A-I per $24 \mathrm{~h}$ (Fig. $4 E$ ). The residual cellular CE fraction consisted for $70 \%$ of $\mathrm{CO}$ and $\mathrm{CP}$, which is again indicative of efficient reesterification of cholesterol in the cytoplasm during efflux. These findings indicate that the CE that entered the cells by uptake of AcLDL/mAb4E4 complexes were metabolized and that the liberated cholesterol was translocated to the membranes, where it became accessible for apo A-I/phospholipid complexes.

Immunostaining. Endarterectomy specimens from 12 patients with confirmed carotid atherosclerosis were collected in phosphate buffered saline containing vitamin $\mathrm{E}$ as an oxidant. Sections of snap-frozen segments were stained with hematoxylin and eosin. Immunostaining with $m A b 4 E 4$ revealed the presence of immunoreactive material in all specimens. The distribution of immunoreactive material in one representative tissue section from one of these patients is illustrated in Fig. $5 B$. Dependent on the specimen and on the area of the tissue section, immunoreactive material was found to be present in cells that appeared morphologically as macrophages ( Fig. $5 C$ ) or as smooth muscle cells (Fig. $5 \mathrm{D}$ ). Furthermore, these cells crossreacted with either PG-M1, a monoclonal antibody specific for human macrophages or with $1 \mathrm{~A} 4$, a monoclonal antibody specific for human smooth muscle $\alpha$-actin. Most probably the immunoreactive material is modified LDL because binding of mAb4E4 to the tissue sections was inhibited with MDA-LDL, but not with native LDL (not shown ). No immu- noreactive material could be detected in these tissue sections with mAb14F8, mAb17C8, and mAb34D8 (not shown).

\section{Discussion}

In the present study, four murine monoclonal antibodies directed against epitopes exposed in chemically modified LDL but not in native LDL, were characterized. $K_{\mathrm{a}}$ values of mAb4E4 for immobilized AcLDL and MDA-LDL were similar, whereas the $K_{\mathrm{a}}$ values of $\mathrm{mAb17C8}, \mathrm{mAb} 14 \mathrm{~F} 8$, and mAb34D4 for AcLDL were 10- to 100-fold higher than those for MDA-LDL. The number of binding sites in AcLDL, expressed per apo B-100 molecule, ranged from 1 for mAb34D8 to 8 for $\mathrm{mAb} 17 \mathrm{C} 8$. The $K_{\mathrm{a}}$ values of mAb4E4 and mAb34D8 for soluble antigens were very similar to those for immobilized antigens, suggesting that the antibodies are not directed against epitopes that are differentially exposed after binding of the antigens to a carrier. The $K_{\mathrm{a}}$ value of mAb14F8 for soluble AcLDL was threefold lower than for immobilized AcLDL. After delipidation of AcLDL and resolubilization of its apo B-100 moiety, the epitopes for mAb4E4, as well as for mAb14F8 and mAb34D8, were poorly reconstituted, whereas that for $\mathrm{mAb} 17 \mathrm{C} 8$ was fully reconstituted, suggesting that the first three monoclonal antibodies are directed against conformational epitopes that require the presence of lipid. A similar antibody, however specific for native LDL, has previously been described (52). Because of the very small number of binding sites per particle and because mAb4E4 does not crossreact with acetylated and malondialdehyde-treated albumin or with maleylated LDL, it is very unlikely that mAb4E4 is directed against a sequential epitope comprising modified lysine residues in the apo B-100 moiety of AcLDL and MDA-LDL. This specificity was previously invoked for monoclonal antibodies MD82 and NA59, used to investigate the distribution of oxidation specific lipid-protein adducts in atherosclerotic lesions (41). It is, however, more likely that the spatial configuration of modified lysine residues in apo B-100 associated with phospholipids, is critical for the binding of mAb4E4, mAb14F8, and mAb34D8. mAb4E4 enhanced the uptake of AcLDL by human THP-1 monocytic leukemia cell-derived macrophages (19) in a dose-dependent manner, resulting in increased intracellular accumulation of CE. Addition of $250 \mu \mathrm{g}$ of the mAb4E4 to cells incubated with $100 \mu \mathrm{g}$ AcLDL resulted in a sixfold increase of the cellular CE levels as compared to cells incubated with AcLDL in the absence of the antibody. The 

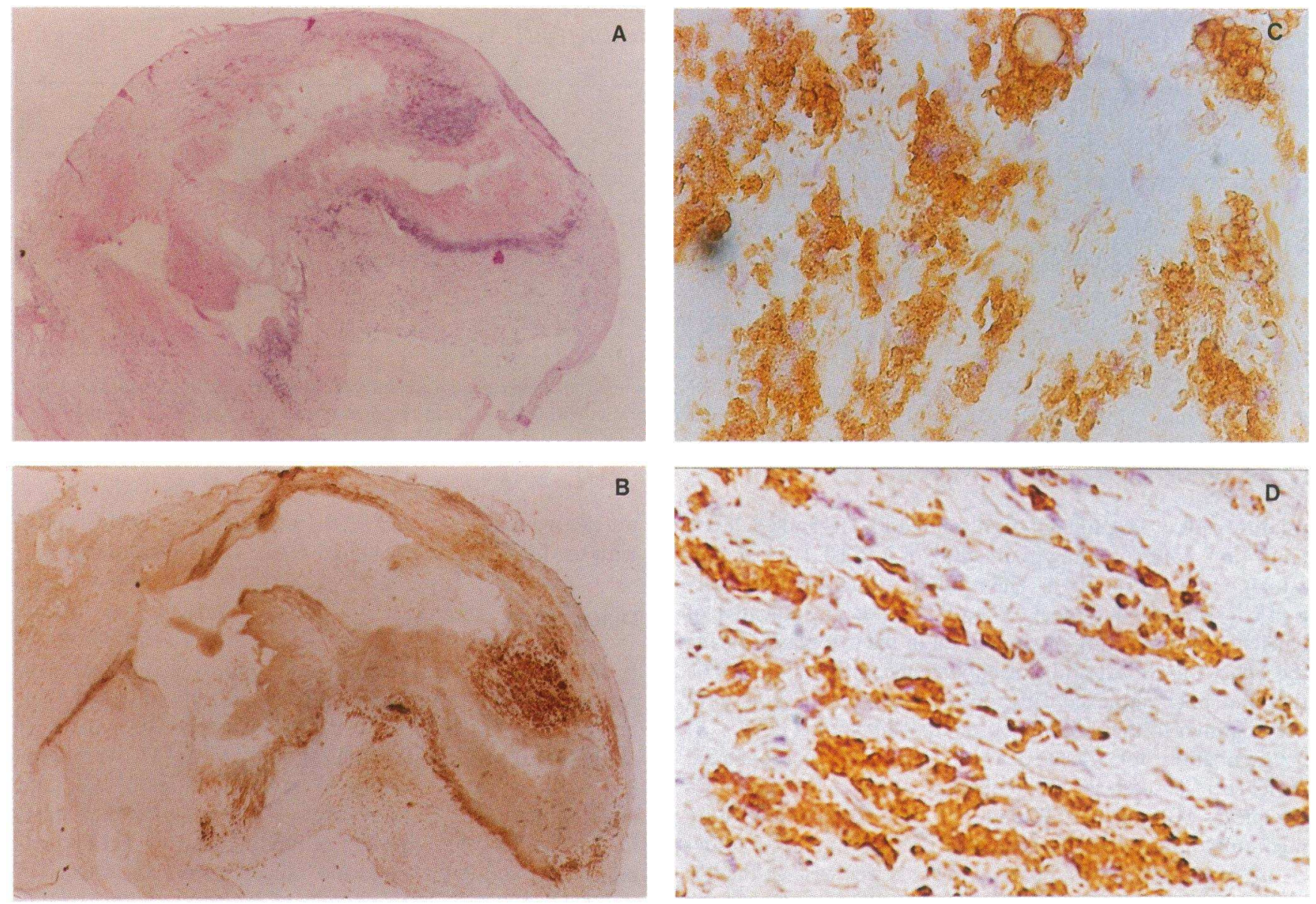

Figure 5. Light micrographs of a carotid endarterectomy specimen. Tissue sections were stained with hematoxylin/eosin $(A)$ or were immunostained with mAb4E4 $(B)(\times 25) .(C)$ and $(D)$ are larger magnifications $(\times 400)$ of different areas of these sections showing accumulation of modified LDL immunostained with mAb4E4 in macrophages $(C)$ or in smooth muscle cells $(D)$.

endocytozed CE were hydrolyzed in the lysosomes ( reverted by chloroquine), and the generated cytoplasmatic cholesterol was reesterified (increase of unesterified cholesterol preceded the increase in $\mathrm{CE}$ and specific increase of cholesteryl oleate in cells supplemented with oleate/BSA complexes) (Fig. 1). Furthermore, the efflux of accumulated cytoplasmic cholesterol was facilitated with apo A-I/dipalmitoylphosphatidylcholine particles, indicating that the pathways for the turnover and translocation of cholesterol from endocytosed AcLDL/mAb4E4 complexes was similar to that for uncomplexed AcLDL (2). Finally, addition of mAb4E4 $(25 \mu \mathrm{g} / \mathrm{ml})$ to the culture medium containing $10 \mu \mathrm{g} \mathrm{AcLDL} / \mathrm{ml}$ resulted in an increased intracellular accumulation of CE. The intracellular CE levels were not different from those in cells incubated with a 10-fold higher dose of AcLDL in the absence of mAb4E4.

It has been previously shown that incubation of human macrophages with immune complexes consisting of human native LDL and rabbit anti-LDL antibodies, resulted in an increased intracellular accumulation of cholesterylesters (53). Most of the immune complexes were taken up via Fc receptors and were degraded more slowly than native LDL. Recently, a monoclonal antibody specific for human native LDL (MB47) was found to enhance the uptake of insoluble LDL aggregates (54). The enhanced uptake was, however, abolished when $\mathrm{F}\left(\mathrm{ab}^{\prime}\right)_{2}$ or Fab fragments of MB47 were substituted for the intact antibody, indicating that the increased uptake was via the Fc receptor pathway (54). In contrast, the stimulatory effect of mAb4E4 on AcLDL uptake was fully preserved in its $\mathrm{F}\left(\mathrm{ab}^{\prime}\right)_{2}$ fragment, indicating that the AcLDL/mAb4E4 complexes were not taken up via $\mathrm{Fc}$ receptors. However, increasing the concentration of mAb4E4 to $2 \mathrm{mg} / \mathrm{ml}$ resulted in a further enhancement of the CE accumulation in the THP-1-derived macrophages, that could be reverted with cytochalasin $\mathrm{D}$. That formation of AcLDL/mAb4E4 aggregates was not required for the enhanced CE accumulation, was further supported by the finding that mAb4E4 could be substituted by its Fab fragment. It has been reported that uptake of aggregates of native LDL (55) and of oxidized and lesion-derived LDL (47) by macrophages results in enhanced CE accumulation in these cells. The uptake of the LDL aggregates was not inhibited by cytochalasin $D$, whereas the uptake of the aggregates of modified LDL was. From these findings, it was concluded that the uptake of the native LDL aggregates occurred through LDL receptor-mediated endocytosis, whereas the uptake of the modified LDL aggregates (added at a 10-fold higher LDL concentration) occurred through phagocytosis. In the present study, the uptake of the AcLDL/mAb4E4 complexes (final concentration of mAb4E4 up to $250 \mu \mathrm{g} / \mathrm{ml}$ ) was not inhibited by cytochalasin $D$, at a concentration at which the uptake of AcLDL aggregates obtained by mechanical disruption of LDL (48) was efficiently inhibited. These data further confirmed that the uptake of these complexes did not occur via phagocytosis. 
It has previously been shown that LDL only interact with the AcLDL scavenger receptor when the positive charges in the available lysine residues have been eliminated, allowing so that available negatively charged residues interact with the receptor (6). Both the density and the geometry of these negatively charged residues appear to be important (6). It is possible that mAb4E4 binding to AcLDL causes a conformational change in the AcLDL particle, resulting in a rearrangement of negatively charged residues and in an increased affinity of the AcLDL for the AcLDL scavenger receptor. In this context, mAb4E4 may be considered to react with a receptor-induced binding site, as been previously described by Zamarron et al. (56). Binding of Fab-fragments of the receptor-induced binding site antibody to fibrinogen resulted in more avid binding to its integrin receptor. Alternatively, binding of intact antibody or of antibody fragments to AcLDL particles might result in an increase of the size of these particles so that each particle can interact with more than one receptor molecule, also resulting in more avid binding of AcLDL particles to the scavenger receptor and subsequent enhanced uptake and degradation. In that respect, mAb4E4 is similar to $\mathrm{mAb} 3 \mathrm{H}$, a monoclonal antibody that is specific for human native LDL, and of which the Fab fragment was found to enhance the uptake of native LDL through LDL receptor endocytosis threefold (57). Because LDL receptors are most probably not exposed at the surface of macrophages in human atherosclerotic lesions (58), it is unlikely that LDLspecific antibodies could enhance LDL-receptor-mediated endocytosis by macrophages in lesions. However, scavenger receptors are exposed at the surface of macrophages in human atherosclerotic lesions (58), whereby antibodies specific for modified LDL may enhance their uptake, resulting in enhanced foam cell generation. The recent finding that serum levels of autoantibodies against oxidized LDL correlate with progression of carotid atherosclerosis might be indicative for immunoglobulin enhanced foam cell generation (18). It remains to be further investigated whether autoantibodies against oxidized LDL may enhance foam cell generation in vivo. Moreover, it is yet unclear whether the generation of modified LDL in human arterial walls (primary event), not only results in the accumulation of these modified LDL in foam cells, but also in the subsequent generation of specific autoimmune antibodies (secondary event), yielding immune complexes that may be taken up more avidly by macrophages via their scavenger receptors. Indeed, recent findings indicate that activation of the immune system may be linked to the pathophysiology of evolving atheroma (for review, see reference 59). Indeed, adhesion of leukocytes to the endothelium via specific endothelial-leukocyte adhesion molecules $(60)$ is one of the earliest morphologic changes after initiation of atherogenesis. Furthermore, analysis of atherosclerotic plaque lymphocytes revealed that the majority of plaque $\mathrm{T}$ cells are memory cells that have been activated by local antigenic stimulation (61). Biologically modified lipoproteins may thereby constitute one class of possible antigens. Moreover, it has been demonstrated that cholesterol can enhance the antigen presenting function of macrophages by inducing the expression of major histocompatibility class II antigens (62). Finally, the recent finding (63) that inflammatory infiltrates in lipid-rich plaques contain both $T$ lymphocytes and B cells in close proximity of lipid-laden macrophages may further support the hypothesis that formation of immune complexes within the plaques may contribute to the further progression of atherosclerotic lesions.

\section{Acknowledgments}

This study was supported by the National Fonds voor Geneeskundig Wetenschappelijk Onderzoek (Project 3.0103.92). We thank Dr. P. Declerck for advice and assistance with the immunological assays, $\mathbf{M}$. Verstreken for technical assistance and B. Verheyden and J. Vangoetsenhoven for secretarial assistance.

\section{References}

1. McGill, H. C., Jr. 1968. Fatty streaks in the coronary arteries and aorta. Lab. Invest. 18:560-564.

2. Goldstein, J. L., and M. S. Brown. 1977. Low-density lipoprotein pathway and its relation to atherosclerosis. Annu. Rev. Biochem. 46:897-930.

3. Goldstein, J. L., Y. K. Ho, S. K. Basu, and M. S. Brown. 1979. Binding site on macrophages that mediates uptake and degradation of acetylated low density lipoprotein, producing massive cholesterol deposition. Proc. Natl. Acad. Sci. USA. 76:333-337.

4. Schaffner, T., K. Taylor, E. J. Bartucci, K. Fischer-Dzoga, J. H. Beeson, S Glagov, and R. W. Wissler. 1980. Arterial foam cells with distinctive immunomorphologic and histochemical features of macrophages. Am. J. Pathol. 100:5780.

5. Gerrity, R. G. 1981. The role of the monocyte in atherogenesis. I. Transition of blood-borne monocytes into foam cells in fatty lesions. Am. J. Pathol. 103:181-190.

6. Brown, M. S., and J. L. Goldstein. 1983. Lipoprotein metabolism in the macrophage: implications for cholesterol deposition in atherosclerosis. Annu. Rev. Biochem. 52:223-261.

7. Ross, R. 1986. The pathogenesis of atherosclerosis: an update. N. Engl. J. Med. 314:488-500.

8. Fogelman, A. M., I. Shechter, J. Seager, M. Hokom, J. S. Child, and P. A. Edwards. 1980. Malondialdehyde alteration of low density lipoproteins leads to cholesteryl ester accumulation in human monocyte-macrophages. Proc. Natl. Acad. Sci. USA. 77:2214-2218.

9. Steinbrecher, U. P. 1987. Oxidation of low density lipoprotein results in derivatization of lysine residues of apolipoprotein B by lipid peroxide decomposition products. J. Biol. Chem. 262:3603-3608.

10. Steinbrecher, U. P., M. Lougheed, W. C. Kwan, and M. Dirks. 1989. Recognition of oxidized low density lipoprotein by the scavenger receptor of macrophages results from derivatization of apolipoprotein B by products of fatty acid peroxidation. J. Biol. Chem. 264:15216-15223.

11. Clevidence, B. A., R. E. Morton, G. West, D. M. Dusek, and H. F. Hoff. 1984. Cholesterol esterification in macrophages. Stimulation by lipoproteins containing apo B isolated from human aortas. Arteriosclerosis. 4:196-207.

12. Morton. R. E., G. A. West, and H. F. Hoff. 1986. A low density lipoprotein-sized particle isolated from human atherosclerotic lesions is internalized by macrophages via non-scavenger-receptor mechanisms. J. Lipid Res. 27:11241134.

13. Hoff, H. F., and J. O'Neill. 1991. Lesion-derived low density lipoprotein and oxidized low density lipoprotein share a lability for aggregation, leading to enhanced macrophage degradation. Arterioscler. Thromb. 11:1209-1222.

14. Boyd, H. C., A. M. Gown, G. Wolfbauer, and A. Chait. 1989. Direct evidence for a protein recognized by a monoclonal antibody against oxidatively modified LDL in atherosclerotic lesions from a Watanabe heritable hyperlipidemic rabbit. Am. J. Pathol. 135:815-825.

15. Ylä-Herttuala, S., W. Palinski, M. E. Rosenfeld. S. Parthasarathy, T. E. Carew, S. Butler, J. L. Witztum, and D. Steinberg. 1989. Evidence for the presence of oxidatively modified low density lipoprotein in atherosclerotic lesions of rabbit and man. J. Clin. Invest. 84:1086-1095.

16. Rosenfeld, M. E., W. Palinski, S. Ylä-Herttuala, S. Butler, and J. L. Witztum. 1990. Distribution of oxidized proteins and apolipoprotein B in atherosclerotic lesions of varying severity from WHHL rabbits: immunocytochemical analysis using antibodies generated against modified and native LDL. Arteriosclerosis. 10:336-349.

17. Palinski, W., M. E. Rosenfeld, S. Ylä-Herttuala, G. C. Gurtner, S. S. Socher, S. W. Butler, and S. Parthasarathy. 1989. Low density lipoprotein undergoes oxidative modification in vivo. Proc. Natl. Acad. Sci. USA. 86:1372-1376.

18. Salonen, J. T., S. Ylä-Herttuala, R. Yamamoto, S. Butler, H. Korpela, R. Salonen, K. Nyyssönen, W. Palinski, and J. L. Witztum. 1992. Autoantibody against oxidized LDL and progression of carotid atherosclerosis. Lancet. 339:883-887.

19. Tsuchiya, S., M. Yamabe, Y. Yamaguchi, Y. Kobayashi, T. Konno, and K. Tada. 1980. Establishment and characterization of a human acute monocytic leukemia cell line (THP-1). Int. J. Cancer. 26:171-176.

20. Havel, R. J., H. A. Eder, and J. H. Bragdon. 1955. The distribution and chemical composition of ultracentrifugally separated lipoproteins in human serum. J. Clin. Invest. 34:1345-1353.

21. Brown, M. S., and J. L. Goldstein. 1974. Suppression of 3-hydroxy-3- 
methylglutaryl coenzyme A reductase activity and inhibition of growth of human fibroblasts by 7-ketocholesterol. J. Biol. Chem. 249:7306-7314.

22. Basu, S. K., J. L. Goldstein, G. W. Anderson, and M. S. Brown. 1976 Degradation of cationized low density lipoprotein and regulation of cholesterol metabolism in homozygous familial hypercholesterolemia fibroblasts. Proc. Natl. Acad. Sci. USA. 73:3178-3182.

23. Haberland, M. E., A. M. Fogelman, and P. A. Edwards. 1982. Specificity of receptor-mediated recognition of malondialdehyde-modified low density lipoproteins. Proc. Natl. Acad. Sci. USA. 79:1712-1716.

24. Habeeb, A. F. S. A. 1966. Determination of free amino groups in proteins by trinitrobenzene sulphonic acid. Anal. Biochem. 14:328-335.

25. Goldstein, J. L., S. K. Basu, and M. S. Brown. 1983. Receptor-mediated endocytosis of low-density lipoprotein in cultured cells. Methods Enzymol. 98:241-260.

26. Cardin, A. D., K. R. Witt, C. L. Barnhart, and R. L. Jackson. 1982 Sulfhydryl chemistry and solubility properties of human plasma apolipoprotein B. Biochemistry. 21:4503-4511.

27. Vanloo, B., J. Morrison, N. Fidge, G. Lorent, R. Brasseur, J. M. Ruysschaert, G. Baert, and M. Rosseneu. 1991. Characterization of the discoidal complexes formed between human apo $\mathrm{A}-\mathrm{I} \mathrm{CNBr}$ fragments and phosphatidylcholine. J. Lipid Res. 32:1253-1264.

28. Matz, C. E., and A. Jonas. 1982. Micellar complexes of human apolipoprotein A-I with phosphatidylcholines and cholesterol prepared from cholate-lipid dispersions. J. Biol. Chem. 257:4535-4540.

29. Holvoet, P., H. R. Lijnen, and D. Collen. 1985. A monoclonal antibody specific for Lys-plasminogen. Application to the study of the activation pathways of plasminogen in vivo. J. Biol. Chem. 260:12106-12111.

30. de St. Groth, S. F., and D. Scheidegger. 1980. Production of monoclonal antibodies: strategy and tactics. J. Immunol. Methods 35:1-21.

31. Voller, A., D. E. Bidwell, and A. Barlett. 1976. Microplate enzyme immunoassays for the immunodiagnosis of virus infections. In Manual of Clinical Immunology. N. R. Rose and H. Friedman, editors. American Society of Microbiology, Washington, DC. pp. 506-512.

32. Ey, P. L., S. J. Prowse, and C. R. Jenkin. 1978. Isolation of pure IgG $_{1}$, $\operatorname{IgG}_{2 \mathrm{a}}$ and $\mathrm{IgG}_{2 \mathrm{~b}}$ immunoglobulins from mouse serum using protein A-Sepharose. Immunochemistry. 15:429-436.

33. Frankel, M. E., and W. Gerhard. 1979. The rapid determinations of binding constants for antiviral antibodies by a radioimmuno assay. An analysis of the interactions between hybridoma proteins and influenza virus. Mol. Immunol. 16:101-106.

34. Hogg, P. J., S. C. Johnston, M. R. Bowles, S. M. Ponds, and D. J. Winzor. 1987. Evaluation of equilibrium constants for antigen-antibody interactions by solid-phase immunoassay: the binding of paraquat to its elicited mouse monoclonal antibody. Mol. Immunol. 24:797-801.

35. Parham, P., M. J. Androlewicz, F. M. Brodsky, N. J. Holmes, and J. P. Ways. 1982. Monoclonal antibodies: purification, fragmentation and application to structural and functional studies of class I MHC antigens. J. Immunol. Methods. 53:133-173.

36. Tijssen, P. 1985. Practice and theory of enzyme immunoassays. In Laboratory Techniques in Biochemistry and Molecular Biology. Vol 15. R. H. Burdon and P. H. Knippenberg, editors. Elsevier/North Holland, Amsterdam. pp. 117121.

37. Via, D. P., L. Pons, L., D. K. Dennison, A. E. Fanslow, and F. Bernini 1989. Induction of acetyl-LDL receptor activity by phorbol ester in human monocyte cell line THP-1. J. Lipid Res. 30:1515-1524.

38. Bury, J., and M. Rosseneu. 1988. Apolipoprotein quantitation by ELISA technical aspects and clinical applications. Rev. Immunoassay Techn. 1:1-25.

39. Vercaemst, R., A. Union, M. Rosseneu, I. De Craene, G. De Backer, and M. Kornitzer. 1989. Quantitation of plasma free cholesterol and cholesteryl esters by high performance liquid chromatography. Study of a normal population. Atherosclerosis. 78:245-250.

40. Lowry, O. H., N. J. Rosebrough, A. L. Farr, and R. J. Randall. 1951. Protein measurement with the fibrin phenol reagent. J. Biol. Chem. 193:265275.

41. Rosenfeld, M. E., W. Palinski, S. Ylä-Herttuala, S. Butler, and J. L. Witztum. 1990. Distribution of oxidation specific lipid-protein adducts and apolipoprotein $b$ in atherosclerotic lesions of varying severity from WHHL rabbits. Arteriosclerosis. 10:336-349.

42. Vanderyse, L., A. M. Devreese, J. Baert, B. Vanloo, L. Lins, J. M. Ruysschaert, and M. Rosseneu. 1992. Structural and functional properties of apolipoprotein B in chemically modified low density lipoproteins. Atherosclerosis. 97:187-199.
43. Hamanaka, R., T. Seguchi, Y. Sato, M. Ono, K. Kohno, and M. Kuwano. 1991. Rapid turnover of low density lipoproteins receptor in human monocytic THP-1 cells. FEBS (Fed. Eur. Biochem. Soc.) Lett. 249:261-263.

44. Goldstein, J. L., S. E. Dana, J. R. Faust, A. L. Beaudet, and M. S. Brown. 1975. Role of lysosomal acid lipase in the metabolism of plasma low density lipoprotein. Observations in cultured fibroblasts from a patient with cholesteryl ester storage disease. J. Biol. Chem. 250:8487-8495.

45. Mahlberg, F. H., J. M. Glick, S. Lund-Katz, and G. Rothblat. 1991. Influence of apolipoprotein AI, AII, and $\mathrm{C}_{s}$ on the metabolism of membrane and cholesterol in macrophages. J. Biol. Chem. 266:19930-19937.

46. Cooper, J. A. 1987. Effects of cytochalasin and phalloidin on actin. J. Cell Biol. 105:1473-1478.

47. Hoff, H. F., and J. O'Neil. 1991. Lesion-derived low density lipoprotein and oxidized low density lipoprotein share a lability for aggregation, leading to enhanced macrophage degradation. Arterioscler. Thromb. 11:1209-1222.

48. Khoo, J. C., E. Miller, P. McLaughlin, and D. Steinberg. 1988. Enhanced macrophage uptake of low density lipoprotein after self-aggregation. Arteriosclerosis. 8:348-358.

49. Liao, W., and C. H. Floren. 1992. Endotoxins inhibit endocytotic catabolism of low-density lipoproteins in HepG2 cells. Hepatology. 16:224-231.

50. van Lenten, B. J., and A. M. Fogelman. 1992. Lipopolysaccharide-induced inhibition of scavenger receptor expression in human monocyte-macrophages is mediated through tumor necrosis factor- $\alpha$. J. Immunol. 148:112-116.

51. Geng, Y.-J., and G. K. Hansson. 1992. Interferon- $\gamma$ inhibits scavenger receptor expression and foam cell formation in human monocyte-derived macrophages. J. Clin. Invest. 89:1322-1330.

52. Marcel, Y. L., M. Hogue, P. K. Weech, and R. W. Milne. 1984. Characterization of antigenic determinants on human solubilized apolipoprotein B. J. Biol. Chem. 259:6952-6957.

53. Lopes-Virella, M. F., R. L. Griffith, K. A. Shunk, and G. T. Virella. 1991 Enhanced uptake and impaired intracellular metabolism of low density lipoprotein complexed with anti-low density lipoprotein antibodies. Arterioscler. Thromb. 11:1356-1367.

54. Khoo, J. C., E. Miller, F. Pio, D. Steinberg, and J. L. Witztum. 1992 Monoclonal antibodies against LDL further enhance macrophage uptake of LDL aggregates. Arterioscler. Thromb. 12:1258-1266.

55. Xu, X.-X., and I. Tabas. 1991. Sphingomyelinase enhances low density lipoprotein uptake and ability to induce cholesteryl ester accumulation in macrophages. J. Biol. Chem. 266:24849-24858.

56. Zamarron, C., M. H. Ginsberg, and E. F. Plow. 1991. A receptor-induced binding site in fibrinogen elicited by its interaction with platelet membrane glycoprotein IIb-IIIa. J. Biol. Chem. 266:16193-16199.

57. Fantappie, S., A. Corsini, A. Sidoli, P. Uboldi, A. Granata, T. Zanelli, P. Rossi, S. Marcovina, R. Fumagalli, and A. L. Catapano. 1992. Monoclonal antibodies to human low density lipoprotein identify distinct areas on apolipoprotein B-100 relevant to the low density lipoprotein-receptor interaction. J. Lipid Res. 33:1111-1121.

58. Ylä-Herttuala, S., M. E. Rosenfeld, S. Parathasarathy, E. Sigal, T. Sarkioja, J. L. Witztum, and D. Steinberg. 1991. Gene expression in macrophagerich human atherosclerotic lesions. 15-lipoxygenase and acetyl low density lipoprotein receptor messenger RNA colocalize with oxidation specific lipid-protein adducts. J. Clin. Invest. 87:1146-1152.

59. Libby, P., and G. K. Hansson. 1991. Biology of disease. Involvement of the immune system in human atherogenesis: current knowledge and unanswered questions. Lab. Invest. 64:5-15.

60. Bevilacqua, M. P., S. Stengelin, M. A. Gimbrone Jr., and B. Seed. 1989 Endothelial leukocyte adhesion molecule-1: an inducible receptor for neutrophils related to complement regulatory proteins and lectins. Science (Wash. DC). 243:1160-1165.

61. Stemme, S., J. Holm, and G. K. Hansson. 1992. T lymphocytes in human atherosclerotic plaques are memory cells expressing CD45R0 and the integrin VLA-1. Arterioscler. Thromb. 12:206-211.

62. Hughes, D. A., P. J. Townsend, and P. L. Haslam. 1992. Enhancement of the antigen-presenting function of monocytes by cholesterol: possible relevance to inflammatory mechanisms in extrinsic allergic alveolitis and atherosclerosis. Clin. Exp. Immunol. 87:279-286.

63. Arbustini, E., M. Grasso, M. Diegoli, A. Pucci, M. Bramerio, D. Ardissino, L. Angoli, S. de Servi, E. Bramucci, A. Mussini, et al. 1991. Coronary atherosclerotic plaques with and without thrombus in ischemic heart syndromes: a morphologic, immunohistochemical, and biochemical study. Am. J. Cardiol. 68:36B-50B 